\title{
APPLICATION OF IMAGE MERGING, SEGMENTATION AND REGION-CLASSIFICATION TECHNIQUES AS A NEW APPROACH FOR THE DETAILED THEMATIC MAPPING OF SOIL-VEGETATION ASSEMBLAGES
}

\author{
RAIMUNDO ALMEIDA FILHO, ÍCARO VITORELLO \& LEONARDO SANT'ANNA BINS
}

\begin{abstract}
RESUMO APLICAÇÃO DE TÉCNICAS DE FUSÃO DE IMAGENS, SEGMENTAÇÃO E CLASSIFICAÇÃO POR REGIÕES COMO UMA NOVA ABORDAGEM PARA O MAPEAMENTO TEMÁTICO DETALHADO DE ASSOCIAÇÕES SOLO-VEGETAÇÃO. Este trabalho discute o uso combinado de técnicas de fusão, segmentação de imagens e classificação por regiões, como uma nova abordagem para o mapeamento semi-automático de associações solo-vegetação. Como primeiro passo, uma fotografia aérea pancromática foi corregistrada com imagens Landsat-TM. A fusão desses produtos, através de transformações no espaço de cores (IHS), gerou um conjunto de imagens híbridas de alta resolução espacial. Essas imagens foram segmentadas e classificadas usando-se um classificador de regiões. A análise das imagens IHS, baseada em informações de campo, permitiu identificar as classes indicadas na imagem classificada, produzindo um mapa temático das diferentes associações de solo-vegetação na área de estudo. Alta precisão e economia de tempo são as principais vantagens do método empregado, em comparação com as técnicas convencionais de fotointerpretação.
\end{abstract}

Palavras-Chaves: Sensoriamento remoto, processamento digital, mapeamento temático

\begin{abstract}
The paper discusses the combined use of image merge, segmentation and region-classification techniques, as a new approach in the semi-automatic mapping of land-cover types. In the first step of the procedure, a digitized panchromatic aerial photograph was co-registered with Landsat-TM images. A hybrid image set with high-spatial resolution was then produced by merging the Landsat images and the aerial photograph, through intensity (I), hue $(\mathrm{H})$ and saturation $(\mathrm{S})$ color transform. Using segmentation techniques, hybrid images were partitioned off into homogeneous regions, and classified according to a region-based classification algorithm. The analysis of the hybrid IHS color composite supported by field data information permitted to identify the classes on the classified image, so producing an accurate thematic mapping of different soil-vegetation assemblages in the study area. Enhanced precision and time saving are the main advantages of this approach, in comparison with the conventional visual interpretation.
\end{abstract}

Keywords: Remote sensing, digital processing, thematic mapping

INTRODUCTION Computer-based classification techniques have been a continuous challenge to those that use remote sensing data for land-use/land-cover and geological mapping. Most of the currently applied classification techniques (supervised or unsupervised methods) are pixel-based, in which the pixel value (gray level) is the only discriminating factor among classes of a multispectral image set. Additionally, the performance of the per-pixel classification techniques have not been improved very much with the advancement in spectral, spatial and radiometric resolutions of the new orbital sensor systems, mainly due to the increased complexity in new remote sensing data acquisition (Kai \& Muller 1991). This is the main reason why visual interpretation of remote sensing images is still widely used to produce thematic maps. However, visual interpretation has two main disadvantages: (a) it is a time consuming activity; and (b) it is dependent on the experience of the interpreter.

To overcome these problems, segmentation techniques have been in development over the past few years, as an alternative method to produce high quality computer-based maps. Similarly to the visual interpretation, in the segmentation techniques, remote sensing images are divided into a number of homogeneous regions, based on several attributes such as area, shape, statistical parameters, and texture. After the images are partitioned into a number of meaningful regions, they may be classified through a region-based classifier.

This study shows, as an example, the application of segmentation and region-based classification techniques to produce a supervised semi-automatic mapping of land-cover units, represented by different soil-vegetation assemblages. Previous publications by the authors (Almeida Filho \& Vitorello 1996,1997$)$ have already demonstrated the potential of this technique in geological applications to enhance areas of hydrothermally altered materials.
STUDY AREA The study area is located in Goiás State, about $400 \mathrm{~km}$ north of Brasilia, central Brazil (Fig 1), comprising approximately $1.5 \times 2.5 \mathrm{~km}$. The region has a tropical savanna climate characterized by a well-defined summer rainy season (October to April) with an average rainfall of $1500 \mathrm{~mm}$, and a drier winter (May to September). Mean annual temperatures range from $24^{\circ} \mathrm{C}$ to $30^{\circ} \mathrm{C}$ (Nimer 1977).

The native vegetation in the study area is the "cerrado", a savanna-like vegetation cover characterized by sparse small trees with twisted trunks and branches, interspersed by shrubs and grasses (Fig 2). During the drier season, leaves on the trees and shrubs remain green, because of their relatively deep root systems (Santos et al. 1977), whereas grasses become dry but turns to a luxuriant green soon after the first rains in the summer.

In the savanna environment, soils are generally characterized by high contents of iron and aluminum oxides, low $\mathrm{pH}$, and deficiencies in organic matter, calcium and magnesium (Ferry 1976). In the study area, the soils show a straightforward relationship with the bedrock geology, comprised by granitic rocks of the Serra do Mendes granitoid(Almeida Filho \& Vitorello 1977). Based on field observations, the soils in the study area may be grouped into three main types. In the central part, predominate shallow whitish lithosols, with quartz rubbles and light fine-grained sands, associated with hydrothermally altered rocks, which show 5Y7/1, 2.5Y7/0, 10 YR5/1 and 10YR6/2 Munsell color indexes. These areas bear sparse vegetation cover with few trees and predominance of grasses and scrub plants. In areas of biotite-granites, soils are darker, thinner, and richer in nutrient and organic matter compared to the areas of hydrothermal alteration. These soils may be classified as 10YR6/4, 10YR6/4, and 10YR7/6 in the Munsell color scheme. In these areas, the vegetation cover is represented by the typical "cerrado", which may be denser or sparser, depending on local conditions, such as soil nutrient 


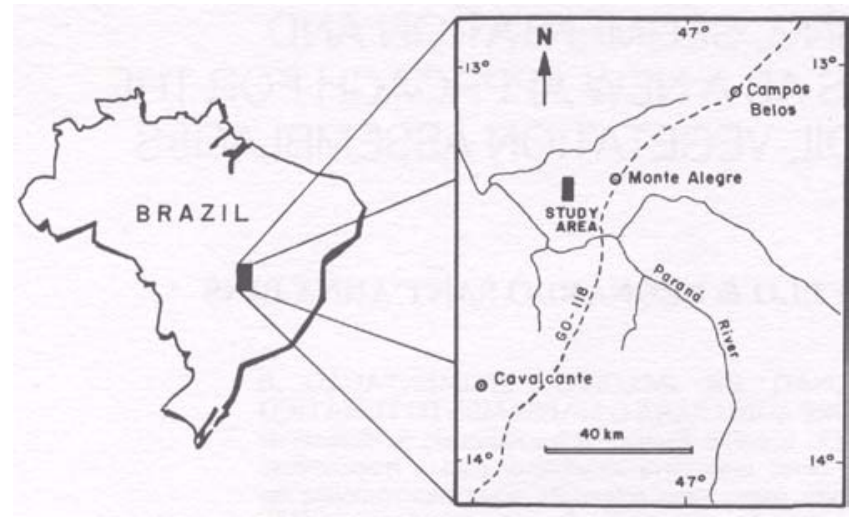

Figure1 - Location of the study area in Central Brazil Figura 1 - Localização da área estudada no Brazil Central.

or soil moisture variations. The intense weathering with the removal of the more soluble materials has concentrated insoluble elements (silica and iron oxides) at the surface and developed extensive reddish-yellowish lateritic crusts in the southern part of the area (Munsell color index of 7.5YR5/6), covered by grasses and sparse shrubs.

\section{IMAGE PROCESSING: RESULTS AND DISCUS-} SION Image Preparation Landsat-TM images (path 221, row 69) were acquired on May 10, 1989, under a solar elevation angle of $42^{\circ}$ and azimuth of $77^{\circ}$. In addition to the orbital images, part of a panchromatic aerial photograph, obtained in August, 1977 by the National Department of Mineral Resources (DNPM), at the original scale of 1:25,000, was digitized, producing a high spatial resolution image with pixel size resampled to 6 by 6 meters. Landsat images (nominal pixel of $30 \times 30$ meters), and the aerial photograph were converted to the Universal Transverse Mercator (UTM) coordinate system, through a least squares first-degree polynomial rectification algorithm based on common control points, extracted from a topographic map at the scale of 1:100,000. Evaluation of the registration accuracy yielded root-mean square error values equivalent to 0.8 and 0.4 of a pixel size for the Landsat images and aerial photograph, respectively. After the corrections, Landsat images and the aerial photograph covering the study area composed sub-scenes with 60 by 86 , and 360 by 516 pixels, respectively.

Among the six Landsat-TM reflective bands, we selected the TM1 $(0.45-0.52 \mu \mathrm{m}), \mathrm{TM} 2(0.52-0.60 \mu \mathrm{m})$, and TM3
(0.63-0.69 $\mu \mathrm{m})$ bands, based on reflectance ground measurements (Almeida Filho \& Vitorello 1996). The images were contrast stretched and later combined through blue, green, and red color filters to produce a natural color composite (Figure $3 a)$. The main advantage of a natural color composite is to facilitate the interpretation of the terrain features (Davis \& Grolier 1984), which nearly appear in their natural colors.

Image Merging The merging of multisensor data through intensity, hue, and saturation color transform (IHS) has been mainly used to produce hybrid products with high spatial resolution, which enhance terrain features (e.g. Welch \& Ehlers 1987, Carper et al. 1990, Yésou et al. 1993). The method is related to the human color perception parameters, defined in terms of intensity (brightness of the color), hue (dominant color: red, green, blue, and color mixtures), and saturation (purity of the color). The procedure involves the transfer of the color parameters from images originally displayed in the red-green-blue domain, to the IHS color space. The reverse transform to the RGB domain permits the IHS images to be replaced by new images.

In order to ensure a precise matching, Landsat images (Figure 3a) and the aerial photograph (Figure 3b) were co-registered, this time using the aerial photograph as a reference. Through this procedure, Landsat images were resampled, by nearest-neighbor method, to the same resolution of the aerial photograph (pixel size of 6 by 6 meters). After these corrections, intensity, hue, and saturation values were calculated from the TM1, TM2, and TM3 bands. In the reverse transform to the RGB domain, the image was replaced by the aerial photograph. The resultant hybrid image keeps the spatial resolution of the aerial photograph and the spectral information of the Landsat-TM bands.

Due to the high spatial resolution of the aerial photograph/Landsat-TM hybrid images, the terrain features produced intricate patterns, making the visual interpretation quite difficult. In order to overcome this problem and to facilitate the generation of a thematic map of the terrain features, segmentation and region-classification techniques were applied to the hybrid images.

Image Segmentation The segmentation technique permits partitioning off images into homogeneous regions, which may have particular common attributes, such as gray levels, mean values, shapes, and textures. (Cross et al. 1988, Corr et al 1989). The approach was based on the region growing technique (Kai \& Muller 1991), implemented in the Geographic Information and Image Processing System (SPRING) developed at INPE (Câmara Neto et al 1996, Bins et al. 1996).

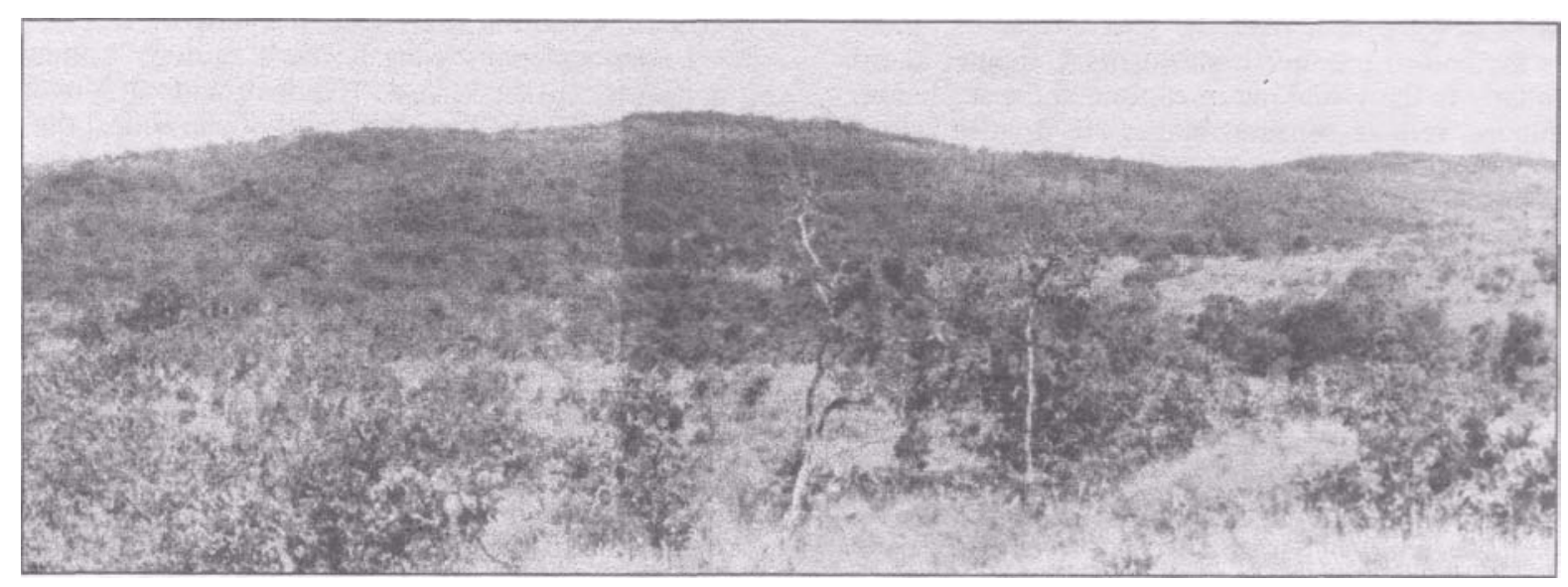

Figure 2 - Field photograph taken from east to west showing vegetation cover characteristics in the study area Figura 2 - Fotografia de campo de leste para oeste mostrando a cobertura vegetal característica da área estudada. 
The entire process can be described according to the following sequential steps: (a) segmentation of the image into pattern cells (one or more pixels); (b) each segment is compared with its neighbors to determine if they are similar or not. If similar, they are merged and the mean gray level of the new segment is updated; (c) the segment continues growing by comparing it with all the neighbors until there is no remaining joinable region, at which point the segment is labeled as a completed region; and (d) the process moves to the next uncompleted cell, repeating the entire sequence until all cells are labeled.
To proceed with the segmentation, a similarity threshold value must be provided by the user. If it is set too low, the growing process will create over-segmented regions, otherwise segments representing different classes will be incorrectly merged together. The choice of an adequate threshold value will greatly depend on the knowledge of the characteristics of the study area and of the objectives and particularities of the application. At the end of the segmentation process an area threshold value (number of pixels) is also specified by the user. A region with an area smaller than this value will be merged with an adjacent region that has the most similar grey

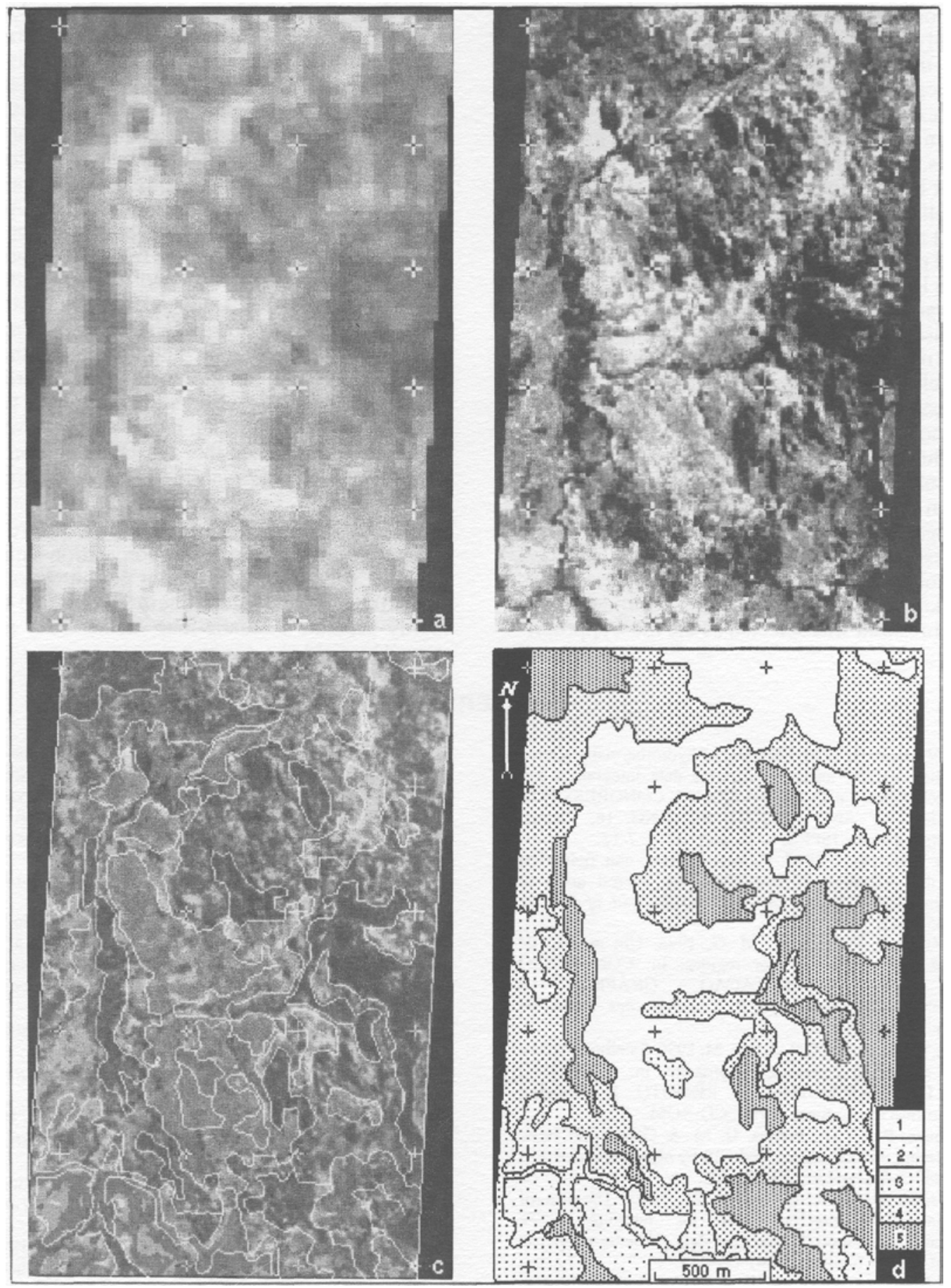

Figure 3 - Landsat-TM natural color composite (a); panchromatic aerial photograph (b); region-classified IHS color composite (c); and thematic-map (d) (refer to the text for explanations about the legend).

Figura 3 - Landsat-TM composto de cores naturais (a); fotografia aérea pancromática (b); composto colorido por classificação regional IHS; e mapa termático (d) (referir ao texto para explicação da legenda). 
level mean. Visual analysis of segmented images using different thresholds permitted to select the similarity threshold and area threshold of 10 and 50, respectively, as the best value to define the soil/vegetation assemblages in the study area. In order to improve the performance of the segmentation process, a low-pass filter was applied to smooth the images (Nagao \& Matsuyama 1979). In this study we applied a median filter to the pre-segmented images, so reducing the variance of the data. The segmented image obtained through this procedure is shown in Figure 3c.

Image Classification A region classifier algorithm (ISOSEG) based on clustering techniques (Bins et al 1992), was used to classify the segmented image. The algorithm can be described by the following three steps:(a) firstly, it is created a list of regions ordered by size (number of pixels); (b) the classes present in the regions are detected; and (c) a $\mathrm{k}$-means algorithm is applied to reclassify the regions, based on the class means. In the first step, the regions are ordered in a decreasing order by size. In the second step, the detection of classes is accomplished as follows: the statistical parameters (mean vector and covariance matrix) of the first region are taken as the initial parameters for the class. This region is then removed from the list. Next, given a chi-square threshold and the statistical parameters of the class, a decision surface is defined (in this case an hyperellipsoid). All the regions in the list which have its mean vector lying inside this hyperellipsoid are marked as not eligible for class detection. Finally, the mean vector for the class is updated. This second step is repeated until the list does not contain any other region eligible for class detection. In the third step, the regions are classified by using the mean vector of each class as the initial centers for the k-means algorithm (Duda \& Hart 1973).

During the image classification procedure, three chi-square thresholds were tested, corresponding to $99 \%, 95 \%$, and $90 \%$ acceptance thresholds. By analyzing the classified images on the screen, and taking into account field data information, the $90 \%$ acceptance threshold was selected as the most appropriate.
Thematic Mapping To proceed with the supervised classification, the predominant groups of land cover units in the region-classified image were identified by comparing the Landsat natural color composite and the hybrid images, based on ground truth information. In this process, some classes were regrouped to express more faithfully the terrain features. This analysis was facilitated since in both natural color composite and hybrid images, surface materials nearly appear in their natural colors. Interpretation/identification of the terrain features is greatly facilitated since we can use an additive color diagram, as reference. So, for instance, shades of green in these images are associated with green savanna vegetation cover, with darker green shades meaning more densely vegetated terrain; light (bluish/whitish) shades result from high reflectance materials in the three visible TM bands (low-vegetated whitish soils); low-vegetated terrain over lateritic soils and duricrusts appear in pale yellow shades, as a result of the contribution of the reddish soils (TM3) and sparse green grassland cover (TM2); and so on. To produce the thematic map of the study area a field classification scale for vegetation cover densities was previously established. According to this scale, areas with up to $40 \%$ vegetation cover were named as "low-vegetated"; from $40 \%$ to $60 \%$ as "vegetated", and more than $60 \%$ as "densely vegetated". Based on these criteria, the thematic-map of the study area was prepared, having the following dominant soil-vegetation assemblages (Figure 3d): (1) low-vegetated terrain upon whitish lithosols; (2) lowvegetated terrain upon lateritic soils and duricrusts; (3) transition areas from low-vegetated to vegetated terrain; (4) vegetated terrain upon latosols; and (5) densely vegetated terrain. Field check confirmed that the used criterion was suitable to express land-cover variability in the study area.

CONCLUSIONS The adopted procedure showed advantageous points compared with conventional methods of image analysis. Besides saving time it permitted to curtail inherent subjectivity of the visual interpretation and to bring forth a highly accurate thematic-map of the study area, as demonstrated by field checking.

\section{REFERENCES}

Almeida Filho, R. \& Vitorello, I. 1996. Mapping of hydrothermally altered areas in vegetated terrain, using multisource data integration and segmentation techniques. In: INTERNATIONAL CONGRESS FOR PHOTOGRAMMETRY AND REMOTE SENSING, 18, Vienna, 1996. Proceedings. Vienna, ISPRS, v. 31, part. B7, p. 7-12.

Almeida Filho, R. \& Vitorello, I 1997. Remote sensing and field data integration in the definition of hydrothermally altered areas in vegetated terrain, central Brazil. International Journal of Remote Sensing, 18:1835-1842.

Bins, L. S., Erthal, G. J. \& Fonseca, L. M. G. 1992. Um método de classificação não supervisionada por regiões. In: CONGRESSO BRASILEIRO DE COMPUTAÇÃO GRÁFICA E PROCESSAMENTO DE IMAGENS, 5. Comunicações. Águas de Lindóia, SBC, v.1, p. 65-68.

Bins, L. S., Fonseca, L. M. G., Erthal, G. J. \& li, F. M. 1996. Satellite imagery segmentation: a region growing approach. In: SIMPOSIO BRASILEIRO DE SENSORIAMENTO REMOTO, 8, Salvador, 1986. Anais. São José dos Campos, INPE, CD-ROM.

Câmara Neto, G., Souza, R. C. M., Freitas, U. M. \& Garrido, J. 1996. SPRING: integrating remote sensing and GIS by object-oriented data modeling. Computer \& Graphics, 20:395-403.

Carper, W. J., Lillesand, T. M \& Kiefer, R. W. 1990. The use of Intensity-Hue-Saturation transformations for merging SPOT panchromatic and multispectral images data. Photogrammetric Engineering and Remote Sensing, 56(4):459-467.

Corr, D. G., Tailor, A. M., Cross, A., Hoggs, D. G, Lawrence, D.H., Mason, D. C. \& Petrou, M. 1989. Progress in automatic analysis of multi-temporal remotely-sensed data. International Journal of Remote Sensing, 10:1175-1195.

Cross, A. M., Mason, D. C. \& Dury, S. J. 1988. Segmentation of remotely-sensed images by a split-an-merge process. International Journal of Remote Sensing, 9:1329-1345.
Davis, P. A. \& Grolier, M. J. 1984. Discrimination of granitoids and mineralized granitoids in the Midyan region, Northwestern Arabian shield, Saudi Arabia, by Landsat MSS data analysis. In: THEMATIC CONFERENCE REMOTE SENSING FOR EXPLORATION GEOLOGY, 3, Colorado Springs, 1984. Proceedings. Ann Arbor, ERIM, v. 1, p. 361-379.

Duda, R. O. \& Hart, P. E. 1973. Pattern classification and scene analysis. New York, Wiley.

Ferry, M. G. 1976. Ecologia dos Cerrados. In: Simpósio Sobre o Cerrado, 4. Brasília, 1976. Anais. Brasília, EMBRAPA, p. 15-33.

Kai, L. \& Muller, J-P. 1991. Segmenting satellite imagery: a region growing scheme. In: IGARSS' 91, 2. Helsink, 1991. Proceedings. Piscataway, IEEE, v. 2: p. 1075-1078.

Nagao, M, \& Matsuyama, T. 1979. Edge preserving smoothing. Computer Graphic and Image Processing, 9(4):391-407.

Nimer, E. 1977. Clima. In: IBGE, Geografia do Brasil: Região Centro-Oeste. Rio de Janeiro, v. 4, p. 35-58.

Santos, L. B., Innocêncio, N. R. \& Guimarães, M. R. S. 1977. Vegetação. In: IBGE, Geografia do Brasil: Região Centro-Oeste. Rio de Janeiro, v. 4, p. 59-84.

Welch, R. \& Ehlers, M. 1987. Merging multiresolution SPOT HRV and Landsat TM data. Photogrammetric Engineering and Remote Sensing, 53:301-303.

Yésou, H.; Besnus, Y.; Rolet, J.; Pion, C. \& Aing, A. 1993. Merging Seasat and SPOT imagery for the study of geological structures in a temperate agricultural region. Remote Sensing of Environment, 43:265-279.

MANUSCRITO A916

Recebido em 28 de abril de 1997

Revisão dos autores em 30 de agosto de 1997 Revisão aceita em 01 de setembro de 1997 